\title{
The Application of Economic Law in Modern Enterprise Business Management
}

\author{
Zhang Jie \\ Shaanxi Technical College of Finance\&Economics Shaanxi, China, 712000
}

Keywords: economic law; business management; modern enterprise

Abstract: With the continuous development of China's market economy, in order to create a better economic environment for enterprises and alleviate economic conflicts, the state has promulgated a series of relevant economic laws, which cover a wide range of economic fields and effectively guarantee the stable development of the national economy. With the development, economic law has been involved in all aspects of social and economic life, modern enterprises in business management also pay more and more attention to the promotion and application of economic law. Based on the application of economic law in modern enterprise business management, this paper first analyzes its feasibility, and then discusses the specific application, in order to provide some reference for enterprise business management.

\section{Introduction}

Economic law is an important tool for the country to lead and manage economic development. The economic law is mainly to adapt to the legislative department gradually formed by the state intervention in the management of social and economic needs. In order to ensure the normal and orderly progress of the national economy, the state uses economic law to regulate conflicts of interest between different market entities, so that there is a law to be allowed between the various entities, and an orderly economic order is established, which is more conducive to economic development. The role and influence of economic law is far more than this.

Economic law is an important legal form of economic intervention, which plays a positive role in liberating social productive forces, protecting and consolidating socialist economic development, and limiting various unfavorable factors for socialist economic development. Economic law is conducive to rational optimization of economic resources, is conducive to improving social and economic benefits, and is conducive to ensuring the fairness of social economy. At the same time, economic law plays an important role in modern business management. It can be seen that economic law is of great significance to China's economic development ${ }^{[1]}$.

\section{Feasibility analysis of economic law used in modern enterprise business management}

In modern enterprise business management, the reason why economic law can be used is because the characteristics of economic law itself are determined, mainly reflected in the following points. 


\subsection{The core of economic law is in the economy}

In the various economic activities of the market economy, the main body of economic activities involved is composed, including economic relations, economic entities, and economic resources. In the continuous development of society, the overall composition needs to be changed and adjusted accordingly. Among them, the law needs to be regulated and restrained. The economic law is generated to adjust social economic activities, and the core of the function lies in economic activities.

\subsection{Economic law covers a wide range}

In the economic activities of society, economic law involves a wide range of issues, affecting both horizontal economic activities and vertical economic activities, and the means used are very diverse. For example, punishment, restrictions, inadequacy, prohibition, etc., it is possible to comprehensively regulate and manage modern enterprise business management activities ${ }^{[2]}$.

\subsection{Economic law arises from the development of commodity economy}

Throughout the human economic activities, economic activities are not active in an environment where the commodity economy is not yet developed, so there is no need for relevant laws to control them. However, with the continuous development of the commodity economy, especially after the development of commodity exchange, economic activities are increasingly active. At this time, relevant laws and regulations are needed to constrain and manage, and economic law is produced in this context. The development of commodity economy is inseparable from economic law, which makes the goods on the market more reasonable, tends to be stable, and makes economic development better and better. Figure 1 is the use of economic law to constrain market commodity price fluctuations.

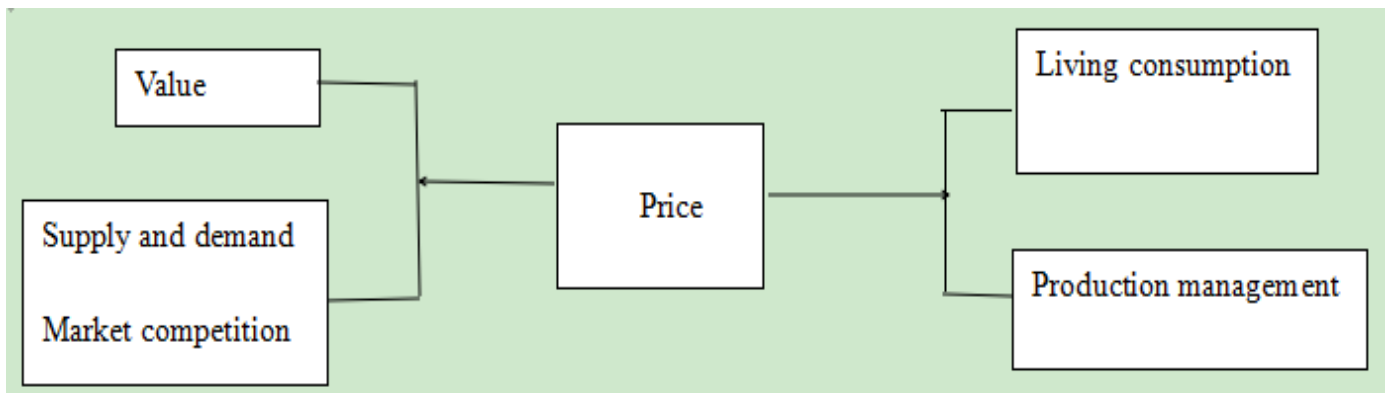

Figure 1 The law of commodity prices under the background of economic law

\subsection{Economic law can regulate and intervene in national economic activities}

Under the continuous development of society, economic activities are characterized by diversification and complexity, and the economic environment is more complicated. Under this situation, it is necessary to strengthen the guidance of the main body of social and economic activities, regulate and intervene in the national economic activities. The use of economic law can achieve the above objectives, and thus maintain the orderly development of economic activities ${ }^{[3]}$.

\section{The application of economic law in the business management of modern enterprises}

With the continuous opening and development of the market economy, economic law has received more and more attention in the business management of modern enterprises. The economic 
law involves all aspects of enterprise management. The normal development of enterprises is inseparable from the adjustment of economic law. In business management, the use of economic law is mainly reflected in the following aspects.

\subsection{The role of economic law in the transformation of enterprise company system}

In the process of transforming the corporate system, it is inseparable from the regulation of economic law. First, the enterprise company will face the problem of unreasonable share structure in the process of reforming the company system. Some enterprises have too much shareholding rights and affect the company's standard operation. This is a common problem in the reform of the company system, which needs to be adjusted and dealt with by economic law. The "Company Law" has made clear provisions on the related issues of enterprises in the reform of the company system, covering a wide range, including: the form of enterprise company system transformation, the steps of enterprise company system transformation and the mode of enterprise company system transformation. Second, the application of the relevant provisions of the economic law can well solve the problem of equity inequality that occurs during the reform of the corporate system. Shareholders can use economic law to maintain their legitimate interests. The Company Law has clear provisions on the issue of the company's shareholding rights. This provision is conducive to safeguarding the legitimate rights of shareholders and promoting social equity. Third, enterprises need economic law to regulate in the management process. There is a relationship between the shareholders' meeting of the company's enterprise system and the board of directors and the board of supervisors. However, if there are problems in the management structure of some enterprises, economic law can also supervise them and improve the management level of enterprises ${ }^{[4]}$.

\subsection{The application of economic law embodied in the management of enterprise ownership and management rights}

For any enterprise, it has ownership and management rights. The former is for the owner of the enterprise, including the rights of possession, use, income and disposal according to law; The latter is for the board of directors and the company manager on behalf of the legal person. Mainly refers to the right to operate the enterprise. However, as far as the current situation is concerned, there is a situation in which enterprise ownership is confused with management rights. If the above situation occurs in state-owned enterprises, it will lead to a large loss of state-owned assets; If the above-mentioned situation occurs in private enterprises, it will lead to asset damage and chaotic management.

Enterprise ownership and management rights are easily confused in the company, in order to effectively avoid the above problems, in order to protect the interests of private enterprises and state-owned enterprises, to take reasonable measures, can take advantage of the economic law explicitly stipulated, and the management of enterprise ownership and management rights, so as to ensure the orderly conduct of the market economy activities.

\subsection{Economic law applies to the protection of corporate intellectual property}

In the face of today's increasingly competitive economic environment, companies have strengthened their awareness of intellectual property protection. In the process of development, in order to compete for superior position in the competition, in the invincible position, there is a phenomenon of using illegal means to plagiarize the core technology of competing enterprises. In order to prevent this phenomenon from happening and maintain a level playing field, it is necessary to apply legal means to limit and manage. In the economic law, the protection of corporate 
technology patents has been clearly defined, and the legal trademarks and copyrights have been strongly protected by the use of laws. China has paid more and more attention to the protection of intellectual property rights of enterprises, and has promulgated relevant laws such as the Trademark Law and the Anti-Unfair Competition Law, effectively realizing the protection of intellectual property rights of enterprises and improving the development of market economy ${ }^{[5]}$.

\subsection{The application of economic law in e-commerce}

With the continuous improvement of the level of science and technology, Internet information technology has developed rapidly, and e-commerce has emerged as the times require, and has developed rapidly in a short period of time. E-commerce is an emerging economic model that emerges with the development of Internet information technology. It also faces many problems. In order to ensure the healthy development of e-commerce, economic law is required to clearly define the responsibilities and interests of e-commerce transactions, strengthen the protection of e-commerce intellectual property rights, ensure the smooth operation of e-commerce, and safeguard the interests of both parties. Figure 2 shows the results of the application and development of economic law in e-commerce in recent years.

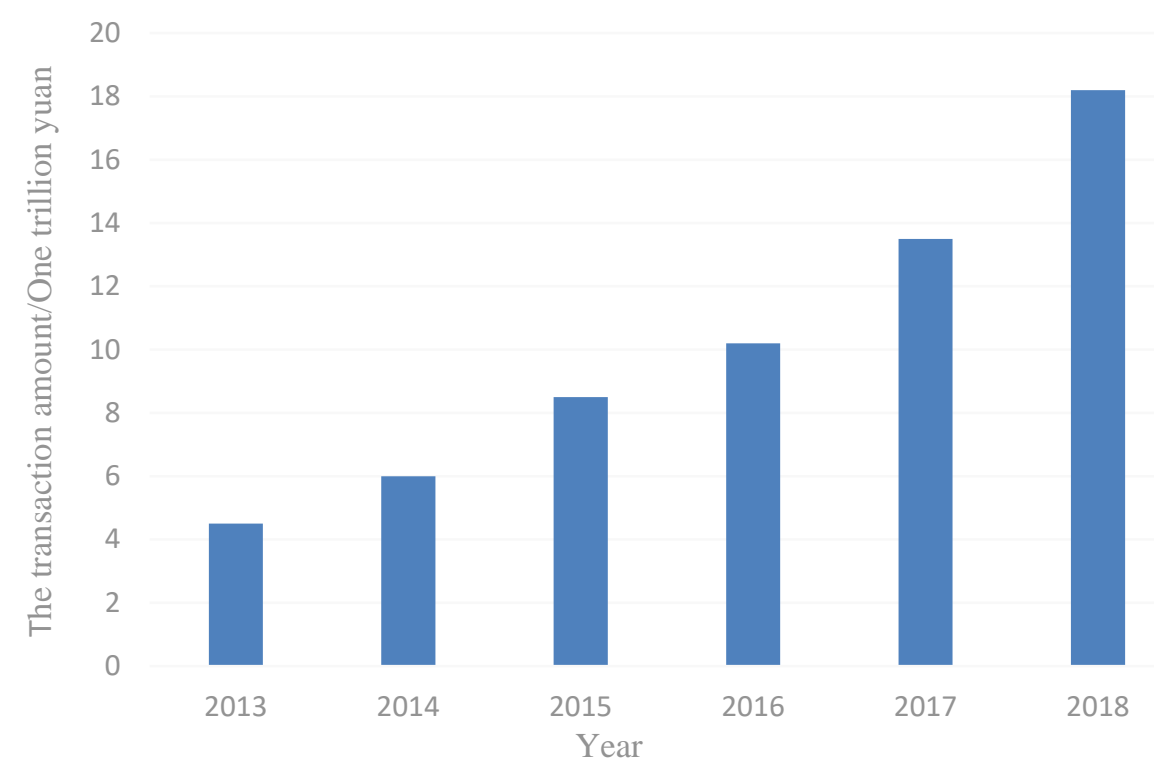

Figure 2 China's e-commerce market transaction scale in 2013-2018

\section{Conclusions}

To sum up, with the continuous development of society and economy, China's market economy system is increasingly improved, and the role of economic law is increasingly prominent. In the modern enterprise business management, economic law can be applied in the enterprise intellectual property protection, corporate system reform, e-commerce, ownership and management. Therefore, in the process of formulating the economic law, the state needs to comprehensively consider the current enterprise development, market characteristics and other factors, establish a good economic order, and promote the healthy, orderly and rapid development of China's economy.

\section{References}

[1] Han Ziqiong. Application of Economic Law in Modern Enterprise Business Management [J]. Modern Marketing 
(Post Journal), 2016(5):36-36.

[2] Lin Ying. Application of Economic Law in Modern Enterprise Business Management [J]. Modern Business, 2013(24): 274-274.

[3] Sun Kai. Discussion on the Application of Economic Law in E-commerce [J]. China Business Review, 2011(10):97-97.

[4] Li Wei. Characteristics of Economic Law and Its Role in Enterprise Management [J]. Northern Economy and Trade, 2018(1):72-73.

[5] Li Bo. The Application of Economic Law in Enterprise Business Management [J]. China Business Review, 2011(22):56-56. 